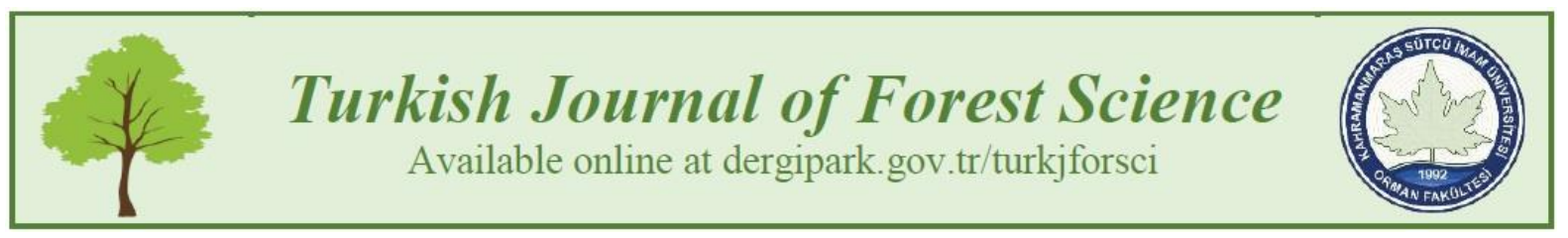

\title{
VEGETATION OF WETLAND BIOTOPES (KURUCAŞILE/ BARTIN/ TURKEY)
}

\author{
Burçin EKİĊ \\ Namık Kemal University, Faculty of Fine Arts, Design and Architecture, 59030, Tekirdağ \\ Corresponding author: bekici@nku.edu.tr
}

Burçin EKİĊ: https://orcid.org/0000-0002-2553-5656

Please cite this article as: Ekici, B. (2020) Vegetation of wetland biotops (Kurucaşile/Bartın/Turkey, Turkish Journal of Forest Science, 4(2), 190-206.

\author{
ESER BILGISI / ARTICLE INFO \\ Araştırma Makalesi / Research Article \\ Geliș 6 Şubat 2020 / Received 6 February 2020 \\ Düzeltmelerin gelişi 13 Mayıs 2020 / Received in revised form 13 May 2020 \\ Kabul 28 Mayıs 2020 / Accepted 28 May 2020 \\ Yayımlanma 24 Ekim 2020 / Published online 24 October 2020
}

\begin{abstract}
Today, biodiversity and ecological diversity are threatened by wrong and intense land use. However, the continuity and maintenance of ecosystems is possible through the existence and sustainable use of biodiversity. Biological inventories are needed for effective and sustainable natural resource management structure. Therefore, it is essential to determine the inventory of the natural asset in the area during ecological planning. Wetlands are ecosystems that shape cultural processes with their ecological importance and contributions to human communities. Recognition and protection of these areas which are open to anthropogenic effects with their environmental enhancing effects, and biological and socioeconomic values are of increasing importance. In this study, vegetation analysis of the wetland biotopes and the immediate surroundings of Kurucaşile (Bartın) district was carried out. In this context, 34 woody and 71 herbaceous plants were determined from 6 sample areas and vegetation composition of these species and their frequencies were determined with BraunBlanquet Method. Accordingly, the most common plants in the area; Alnus glutinosa subsp. glutinosa, Platanus orientalis, Salix alba, Rhododendron ponticum subsp. ponticum, Buxus sempervirens, Smilax excelsa, Petasites hybridus, Sambucus ebulus and Anagallis arvensis var. arvensis. Petasites hybridus is dominant taxa. By this way, it is aimed to create a database for the sustainable use of natural areas by explaining the wetland potential of the area.
\end{abstract}

Keywords: Wetland, habitat, flora, Bartın, Turkey.

\section{SULAK ALAN BIYYOTOPLARINDA VEJETASYON ANALIZI (KURUCAŞILE/ BARTIN/ TÜRKIYE)}

ÖZET: Günümüzde yanlış ve yoğun arazi kullanımları ile biyolojik ve ekolojik çeşitlilik tehdit altına girmektedir. Oysa ekosistemlerin devamı ve bakımı biyoçeşitliliğin varlığı ve sürdürülebilir kullanımı ile mümkün olmaktadır. Etkin ve sürekliliği olan doğal kaynak

This study was produced from the $\mathrm{PhD}$ thesis titled "Mapping of the Biotopes in the Kurucaşile (Bartın) Coastline and its Surrounding Areas" 
yönetim yapılanması için biyolojik envanterlere ihtiyaç duyulmaktadır. Bu nedenle ekolojik planlama yapılırken alandaki doğal varlığın envanterinin tespiti şarttır. Sulak alanlar, ekolojik önemleri ve insan topluluklarına katkılarıyla kültürel süreçleri de şekillendiren ekosistemlerdir. Çevre kalitesini arttırıcı etkileri, biyolojik ve sosyo- ekonomik değerleri ile atropojenik etkiye açık bu alanların tanınması ve korunması günümüzde önemi gittikçe artmaktadır. $\mathrm{Bu}$ araştırmada Kurucaşile (Bartın) ilçesinin sahip olduğu sulak alan biyotopları ve yakın çevresinin vejetasyon analizi gerçekleştirilmiştir. Bu kapsamda 6 örnek alandan 34 odunsu, 71 otsu bitki tespit edilmiş, bu bitkilerin Braun Blanquet Yöntemi'ne göre vejetasyon örtüsünün tür kompozisyonu ve türlerin örnek alanlarda tekrarlanma sıklıkları saptanmıştır. Buna göre alandaki en yaygin bitkiler; Alnus glutinosa subsp. glutinosa, Platanus orientalis, Salix alba, Rhododendron ponticum subsp. ponticum, Buxus sempervirens, Smilax excelsa, Petasites hybridus, Sambucus ebulus ve Anagallis arvensis var. arvensis'tir. Petasites hybridus ise baskın tür olarak belirlenmiştir. Bu çalışma ile alanın sulak alan potansiyeli açıklanarak doğal alanların sürdürülebilir kullanımı için veri tabanı oluşturulması amaçlanmıştır.

Anahtar kelimeler: Sulak alan, habitat, flora, Bartın, Türkiye.

\section{INTRODUCTION}

In developing countries, many of the current land use policies do not ensure ecological sustainability, resulting in degradation of habitats. Today, natural habitats and ecosystems are destroyed and 12 million hectares of forests are lost (UN, 2020). 35\% of the wetlands in the world have been destroyed since 1970 (Ramsar Convention Secretariat, 2018). The threat to biodiversity increases because of the damages in habitats and ecological and economic losses occur. However, it is known that biodiversity, which is a natural resource, strengthens the green economies of countries as billions of people are directly and indirectly connected to it (Shah \& Ayiemba, 2019). Therefore, the importance of habitat conservation is increasing, and potential ways, to support environmental protection efforts are being explored throughout the world (Chokor, 1992).

Sustainable land use planning and societies' living in healthy environments will be ensured through obtaining knowledge about the area (Naveh, 2007). Therefore, data collection is very important for protection of nature (Müller et al., 2003). Advanced data collection, analysis and data management ensure a scientific understanding of the area and long- term management of ecosystems. For this reason, the basic data within the scope of planning was determined as biotope research (Hong et al., 2005).

It is very difficult to conserve a biotope type without clearly identifying it and performing vegetation analysis. Biotope maps include biotope maintenance plans that enable intended conservation of biotopes in the region that are worth preserving in the long term and the motives for conservation, as well as planning such as biotope development plans to restore biotopes (Ssymank \& Dankers, 1996). It also enables to develop an ecological view of biodiversity in spatial planning and to develop tools to protect biodiversity. Thus, decisions about biodiversity are made according to the ecological characteristics of the area (Löfvenhaft et al., 2002).

Wetland biotopes, which constitute the subject of our research, are of great importance in terms of preserving and maintaining biological diversity and ecological balance. These areas are ecosystems of physical, chemical and biological elements such as soil, water, plant, animal species and nutrients (Korkanç, 2004). According to the definition in the Ramsar Convention, 
wetlands are all swamp, peat or water- covered areas at ebb tide period and with not more than 6- meters depth, either natural or artificial permanent or temporary, static or dynamic and with fresh, bitter or salty water (Ramsar Convention Bureau, 1992). Wetlands are very important biotopes that protect and improve water quality, soften the climate, produce oxygen, purify nutrients, control erosion and shape the nature and cultural processes with their visual effects that are subject to recreational activities (Çakır \& Çakır (2019); Atalay et al., (2019); Gren et al., (1994); Kimmel et al., (2010); Wang et al., (2008); Kiymaz, (2010)). Although these ecosystems cover less than $1 \%$ of the total amount of water on Earth, they contain $40 \%$ of all living species in the world (Maraşlığlu \& Salur, 2016). Although ecological and economic values of wetlands in Turkey has begun to be understood in recent years and important steps have been taken, there are serious threats and problems related to the protection and management of wetlands (Karadeniz et al., 2009). These highly sensitive ecosystems are adversely affected as a result of anthropogenic effects, which are increasing especially with the acceleration of urban development. Impairment of wetland functions leads to habitat destruction, reduced soil fertility, loss of biodiversity and temperature rise in climate (Wang et al., 2008). Studies to establish the balance of conservation and use can be made by defining the area and determining its natural potential. However, in our country, studies on the presence of flora, which is one of the main characteristics of wetlands, are quite inadequate. Despite some old- dated studies, the first serious research in this area entitled "Turkey's Wetland and Vegetation" was carried out by Seçmen \& Leblebici (1997) (Özbey et al., 2015). Nowadays, it is important to investigate these ecosystems which are open to anthropogenic oppression and have a very dynamic structure in terms of biodiversity.

In this research, vegetation analysis of the wetlands biotopes and the immediate vicinity of Kurucaşile (Bartın) district were carried out. Similar studies were conducted in the surrounding of the research area and these are; Yatgın (1996), Başaran (1998), Y1lmaz (2001), Vurdu vd. (2004), Yılmaz (2004), Kaya and Başaran (2006), Ekici (2012), Ekici (2017), Sarı Nayim (2010), Sarı Nayim and Ayaşlıgil (2015) and Sarı Nayim (2017). The reason why Kurucaşile has been selected as a research subject is that it increases the richness in biodiversity with its diversity of habitats and ecosystems. However, the lack of recognition of the natural and cultural values of the area prevents doing necessary and sufficient studies on nature protection. In this study, wetland biotopes were determined and their natural potential was revealed in order to determine the sensitivity of habitats in the area and to form a basis for decisions regarding the conservation- use balance.

\section{MATERIALS AND METHODS}

Kurucaşile is established on an area of $1546 \mathrm{~km}^{2}$ on the Western Black Sea coast (Figure 1). The surface area is $159 \mathrm{~km}^{2}$ (Çilsüleymanoğlu, 1996). The district is surrounded by the Black Sea, Bartın, Cide and Amasra on the north, south, east and west respectively. The material of the study consists of wetlands biotopes in Kurucaşile district (Figure 2). Wetlands consist of rivers and a waterfall. The rivers are in the form of stream and streamlet and most of them are in the coastal area. All of these are poured into the Black Sea. Tekkeönü, Başköy, Elvanlar and Kapisuyu Stream are among the most important rivers of the district. The highest flow of these rivers are in February and March. The flow rate is very low in summer. In addition to the rivers, the hydrological structure also includes Gölderesi Waterfall, which starts at an altitude of 300 $\mathrm{m}$, spans about $12 \mathrm{~km}$ long and pours into Çambu Bay. In Gölderesi there are four 6-10 m high 
waterfalls and small lakes with a diameter of approximately $3 \mathrm{~m}$, varying in size according to the seasons.

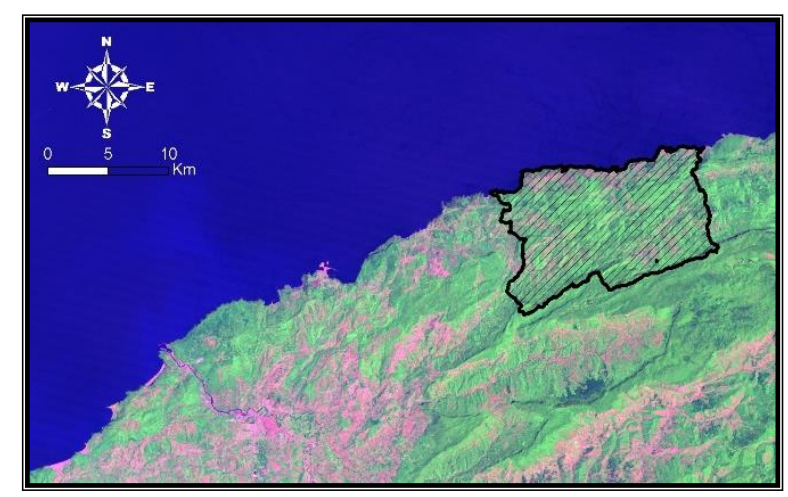

Figure 1. Satellite Image of Research Area

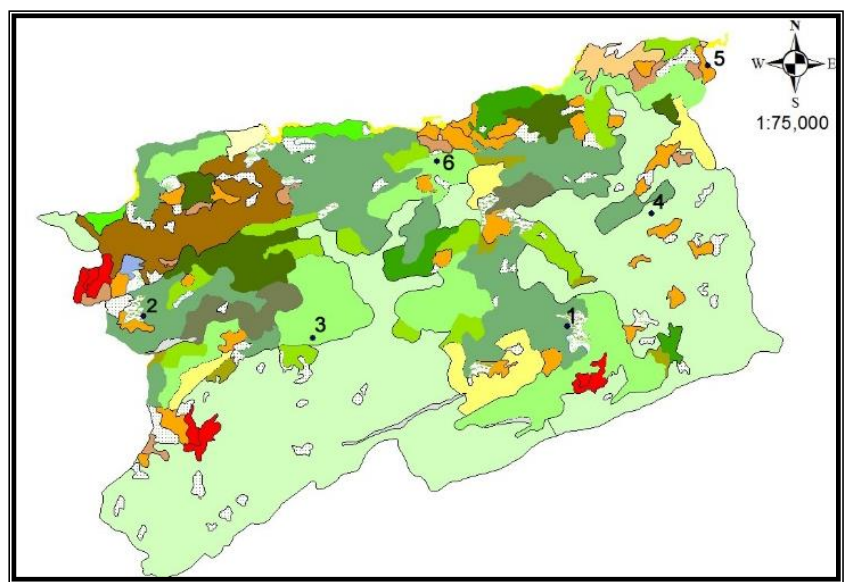

Figure 2. Wetlands of Kurucaşile (1: Başköy Stream, 2: Elvanlar Stream, 3: Gölderesi

Waterfall, 4: İlyas Stream, 5: Kapısuyu Stream, 6: Tekkeönü Stream)

When the natural structure of the research area is examined, it is seen that it has a complex structure in the coastal areas and is more plain in the inner parts. There are Cenozoic and Mesozoic sedimentary rocks in the area. Cenozoics belong to Quaternary formations and Mesozoics belong to Cretaceous formations (Haner \& Türk, 2000). In the research area, there are 4 large soil groups; gray brown podzolic, red yellow podzolic, alluvial and colluvial. The most common large soil group in the district is gray brown podzolic soils. Kurucaşile has the characteristics of temperate Black Sea climate which may receive rainfall in all seasons. According to Bartın meteorological station data, the average annual temperature is $13^{\circ} \mathrm{C}$, the hottest month is August $\left(23.4^{\circ} \mathrm{C}\right)$, the coldest month is January $\left(4.9^{\circ} \mathrm{C}\right)$, and the average annual rainfall is $1026.6 \mathrm{~mm}$. According to the water balance sheet prepared in regard to the Thornthwaite method, the research area is in the "humid climate" group. Accordingly, in terms of temperature it has "mesothermal climate", and it has no or very little water deficit. The diversity of Kurucaşile district and its immediate surroundings in terms of topography, climate, geology and geomorphological characteristics, also increases the diversity of the habitat. This diversity enriches the flora. The Euxine section of the Euro-Siberian floristic region dominates the northern slopes of the area facing the Black Sea due to the mild and humid sea climate. Pseudo maquis elements are also seen locally.

The study was carried out in three phases; analysis of the existing data of the area and the research subject, field studies and evaluation of the data obtained from field studies. In the first 
phase, information about vegetation and climate, soil, geological, geomorphological and hydrological data were collected to characterize the growth medium. In the second phase, floristic researches were started. In this context, field studies were carried out in the sample areas and a plant was collected for diagnostic purposes and a "Field study form" was completed for each sample area. With this form, data were obtained about cover value of herbaceous vegetation, amount, combination and dominance of species, cover ratio of woody vegetation, length of layers and the size, coordinates, growth medium characteristics and habitat value of the sample area. Species composition of vegetation cover and frequency of species in sample areas were determined by means of this field study form. Accordingly, the characteristic species representing the biotope type were determined. As vegetation is an indicator in floristic studies, Braun- Blanquet (1964) method was used to show the ecological structure. With this method, the amount of existing plants in an area covered with vegetation is determined by observation and coverage values are expressed as \% of the total area (Blanquet, 1964).

In the identification of the plants collected from the field and made into herbarium material, the herbarium of Hacettepe University Faculty of Science was used. In addition to herbarium facilities, especially, the works of Davis (1965- 1985), Davis et al. (1988) and Güner et al. (2000), as well as Symonds \& Chelminsky (1958), Symonds \& Merwin (1963), Tutin et al. (1964), Tutin et al. (1968- 1980), Hora (1981), Fitter et al. (1986), Yaltırık (1988), Schönfelder \& Schönfelder (1990), Gibbons (1993), Y1lmaz (1993), Baytop (1997), Uluocak (1994), Schönfelder \& Schönfelder (1995), Seçmen et al. (1995), Yaltırık \& Efe (1996), Kremer (1998), Erik et al. (1998), Zeydanlı et al. (1999), Altan (2000), Ekim et al. (2000), Durmuşkahya (2006), Akman et al. (2007), Namıkoğlu (2007) and Özhatay et al. (2010) were used.

\section{RESULTS}

Since a large part of the district is covered with forests and accordingly, there is plenty of rainfall, there are many creeks and streams of various sizes. All of these rivers originating from the mountains of Northern Anatolia pour into the Black Sea. Therefore, the coastal area displays a rich structure in terms of water availability. Snowy mountain regime prevails in the upstream basins of the rivers. Therefore, the water formed by melting snow has a significant place in the feeding of the river. The flow rate decreases at a great extent in winter due to snow and frost. The flow rates and regimes of rivers are irregular depending on the season. The highest flow is observed in February and March. In summer, the flow rate is very low. The fact that streams and creeks do not have a stable regime causes flooding. This threatens human life as well as the surrounding vegetation.

Başköy, Elvanlar, İlyas, Kapısuyu and Tekkeönü Stream are among the most important rivers in the research area. The streams found in these areas, where marn, limestone and sandstone bedrock are spread, are covered with trees and shrubs with high need of moisture.

The vegetation in the slope areas on both sides of the river bed consists of pseudomaki elements near the shore and this vegetation becomes Tilia argentea communities on the north- facing slopes dominated by limestone. Carpinus orientalis subsp. orientalis and Fagus orientalis communities stand out in the rivers and slopes in the inland. In rural settlements, hazelnut and poplar plantations are concentrated in the areas close to the rivers of agricultural areas. 
In the south, sand and gravel accumulates in the parts where the creek beds and the slopes facing them are less inclined. The sides of these kinds of streams are covered with forests (Figure 3). The streams form woody or shrubs with humid character in the level areas where they pass. In these areas, where Alnus glutinosa subsp. glutinosa, Carpinus betulus, Fagus orientalis and Salix alba are dominant, Acer campestre subsp. campestre and Platanus orientalis species are also seen locally. The shaded undercover of tall trees is covered by Buxus sempervirens, while the open spaces contain Corylus avellana var. avellana, Ligustrum vulgare, Pyracantha coccinea, Rubus caesius and Smilax excelsa bushes. Alnus glutinosa subsp. glutinosa, Platanus orientalis and Tilia argentea communities are dominant in the northern slopes, while these taxa are replaced by Juglans regia, Laurus nobilis, Olea europaea subsp. sylvestris, Salix alba, Populus nigra ssp. nigra and Prunus $x$ domestica species as you move to the coastal areas. Myrtus communis subsp. communis, Phillyrea latifolia, Rosa canina and Rubus hirtus shrubs play an important role in these river slopes (Appendix 1).

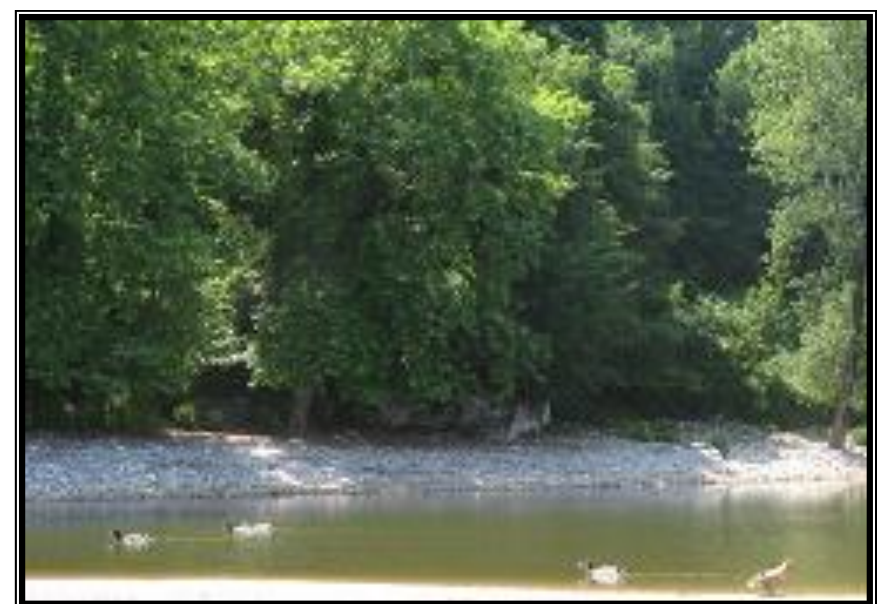

Figure 3. Tekkeönü Stream Surrounded By Carpinus betulus Forests

Typha latifolia reeds are widespread along the rivers. As you go from the sea to the inner parts, it is seen that the river banks are covered with Petasites hybridus (Figure 4). Galega officinalis, Lotus corniculatus var. corniculatus, Lysimachia verticillaris, Mentha x piperita, Ranunculus constantinopolitanus, Rumex crispus, Trifolium campestre and Veronica chamaedrys species are dominant in humid herbaceous vegetation at the water sides (Table). These taxa are locally accompanied by Hedera helix, Orobanche ramosa, Primula vulgaris subsp. vulgaris and Pteridium aquilinum species that develop densely under trees (Appendix 1).

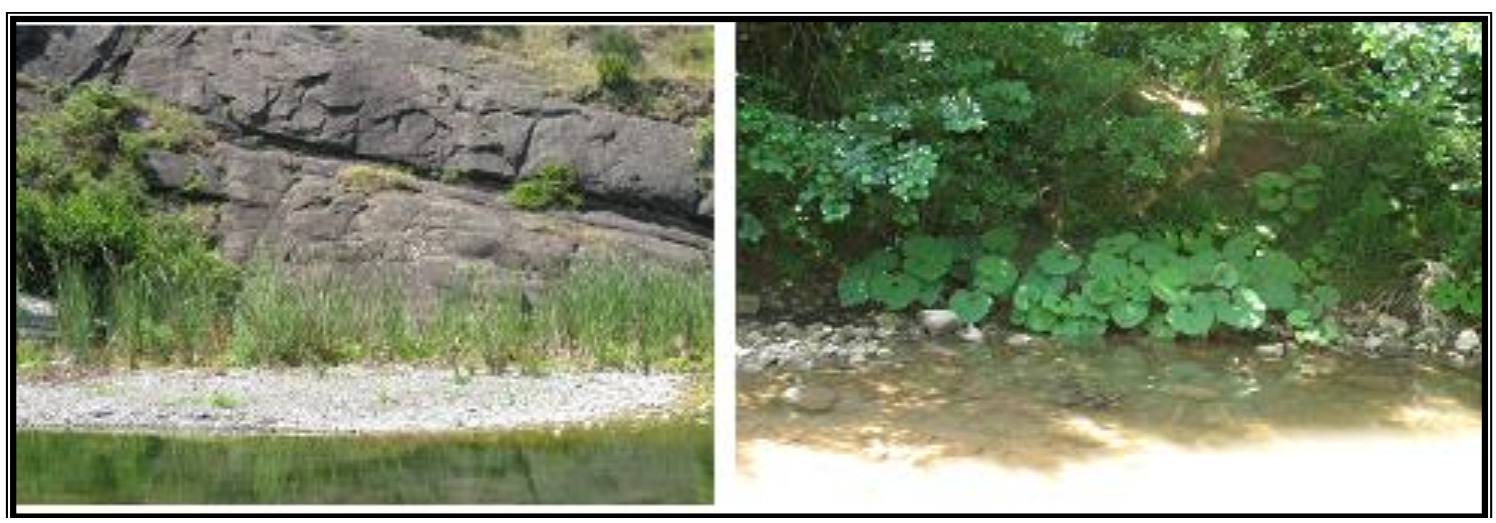

Figure 4. Typha latifolia and Petasites hybridus, Which Live Along The Banks Of The Elvanlar Stream 
Anagallis arvensis var. arvensis, Arabis caucasica subsp. caucasica, Arabis turrita, Carduus nutans, Cionura erecta, Cirsium vulgare, Coronilla varia subsp. varia, Crepis foetida subsp. rhoeadifolia, Erodium cicutarium subsp. cicutarium, Euphorbia helioscopia, Glaucium flavum, Hordeum murinum subsp. leporinum var. leporinum, Iris pseudacorus, Leucojum aestivum, Lythrum salicaria, Potentilla reptans, Prunella vulgaris, Rapistrum rugosum, Rostraria cristata var. cristata, Sambucus ebulus, Sedum stoloniferum, Sherardia arvensis, Sophora jaubertii, Tanacetum parthenium and Torilis arvensis subsp. arvensis taxa have an important place in the sunny openings on the riverside. These species are partly accompanied by meadow vegetation elements such as Argyrolobium biebersteinii, Barbarea vulgaris, Bellis perennis, Convolvulus arvensis, Lolium perenne, Phalaris arundinacea, Plantago lanceolata, Poa trivialis, Trifolium hybridum var. hybridum and Trifolium lappaceum (Appendix 1).

Pollution occurs in these biotopes due to domestic wastes. Growth conditions caused by these factors have enabled the development of ruderal vegetation. Other plants in these areas where Cynoglossum creticum and Euphorbia amygdaloides var. amygdaloides taxa are dominant have been identified as Anthemis cotula, Chenopodium album subsp. album var. album and Ficus carica subsp. carica (Appendix 1).

Another formation of wetland biotopes within the boundaries of the study area is the Gölderesi Waterfall. Gölderesi is an important wetland system formed by stable water surfaces and streams. Fagus orientalis communities which grow best in humid environments are spread in the south of Gölderesi. In the areas where the river approaches the waterfall, these plant communities are replaced by mixtures dominated by Alnus glutinosa subsp. glutinosa, Carpinus orientalis subsp. orientalis and Quercus infectoria subsp. infectoria species. Ilex colchica, Mespilus germanica, Rhododendron ponticum subsp. ponticum, Rubus caesius, Ruscus hypoglossum, Smilax excelsa and Vaccinium arctostaphylos form the shrub layer of woody vegetation accompanied by Laurocerasus officinalis and Sorbus torminalis var. torminalis. There are scrub elements consisting of Arbutus unedo, Cistus creticus and Staphylea pinnata taxa on the south- facing slopes of the area which is sheltered from wind and cold weather conditions (Appendix 1).

The fact that Gölderesi and its surrounding areas are not highly covered, offers a floristic richness in terms of herbaceous vegetation. Typical vegetation elements dominated by Mentha aquatica, Nasturtium officinale, Petasites hybridus, Tussilago farfara and Polystichum setiferum taxa stand out on the waterfronts (Figure 5). Other herbaceous elements in the area consist of Argyrolobium biebersteinii, Barbarea vulgaris, Cerastium glomeratum, Cirsium hypoleucum, Crepis foetida subsp. rhoeadifolia, Dorycnium graecum, Fragaria vesca, Galium palustre, Petrorhagia velutina and Veronica serpyllifolia. Euphorbia amygdaloides var. amygdaloides, Galium verum subsp. verum, Hypericum bithynicum and Poa trivialis taxa occupy a large space in sunny openings (Appendix 1). 


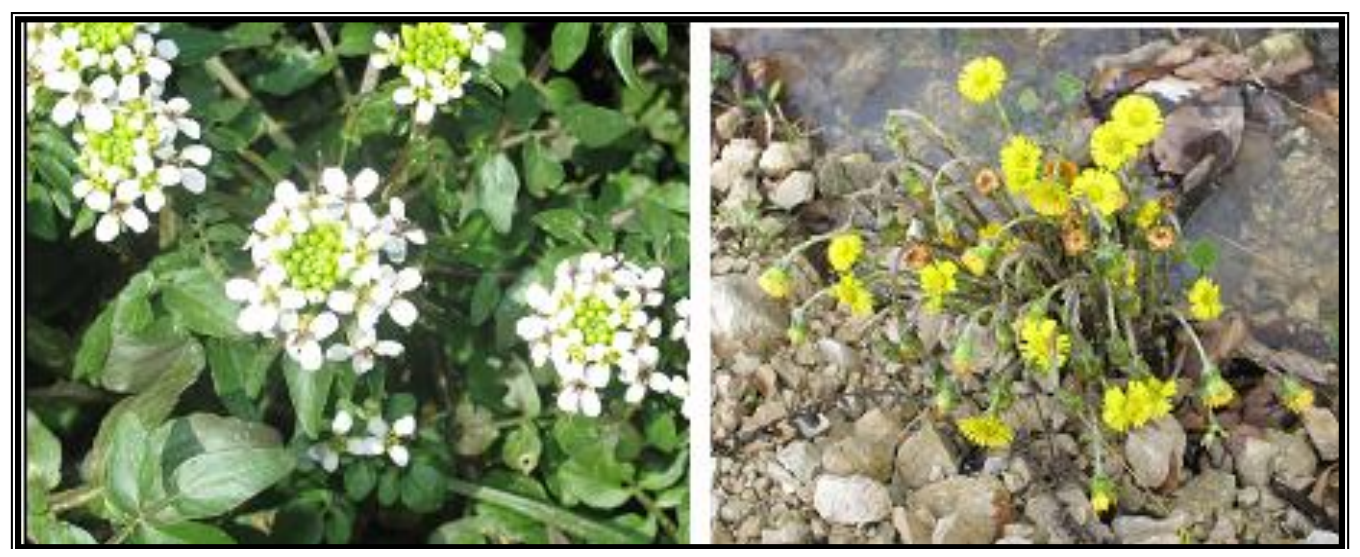

Figure 5. Moist Vegetation Samples; Nasturtium officinale And Tussilago farfara (Gölderesi Waterfall)

Geophytes such as Crocus ancyrensis, Cyclamen coum var. coum, Galanthus plicatus subsp. byzantinus, Leucojum aestivum and Muscari neglectum accompanies Cardamine hirsuta, Cardamine quinquefolia, Geranium robertianum, Hedera helix and Viola odorata taxa spreading in shady under cover of tall trees (Figure 6) (Appendix 1).

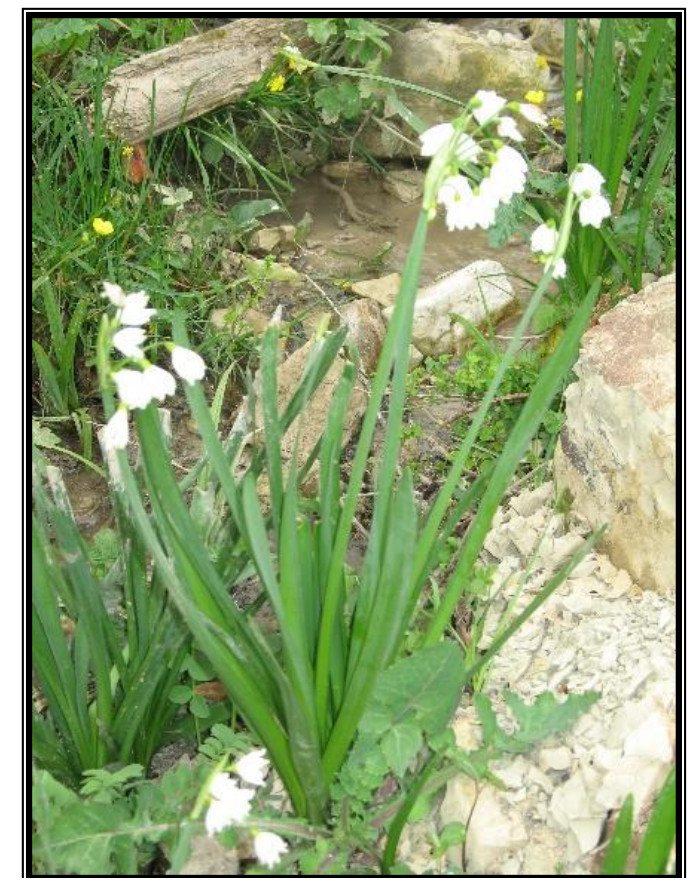

Figure 6. Leucojum aestivum, One Of The Geophyte Plants In The Area

\section{DISCUSSION}

Unplanned increase of urban development brings environmental pollution and causes contraction or elimination of limited wetlands. For this reason, the presence of wetlands, its potential, and its natural characteristics have recently taken their place near the top on the world agenda (Atalay et al., 2019). Ecosystems around water resources make up a small portion of forest areas but are highly effective for biodiversity, wildlife and human life (Yılmaz \& Çiçek, 2003). Therefore, it is important to reveal their natural and cultural characteristics for the conservation and sustainable use of these areas. 
Within the scope of the research, the wetland biotopes in Kurucaşile (Bartın) district were determined and the floristic composition of 6 vulnerable sample areas open to human pressure were explained. These areas are Başköy, Elvanlar, Gölderesi, İlyas, Kapısuyu and Tekkeönü Stream. The flow and regimes of these rivers, which occupy a wide place in the research area, change depending on the season and this causes flooding especially in spring. Accordingly, human life as well as the surrounding vegetation is under threat. Fresh water, which provides irrigation water for agricultural areas, is destroyed due to pollution from settlements. It has been determined that the pollution caused by construction and domestic wastes in the river beds negatively affects the quality, fauna and flora of the water and this pollution is seen intensely in Elvanlar and Başköy streams.

The research area provides a living environment for geophytes such as Cyclamen coum var. coum, Crocus ancyrensis, Galanthus plicatus subsp. byzantinus, Iris pseudacorus and Leucojum aestivum (Figure 7). Among these taxa, Leucojum aestivum is "VU" (Vulnerable) according to IUCN Red List categories (Ekim et al., 2000), while Crocus ancyrensis and Galanthus plicatus subsp. byzantinus are endemic and "LR" (Less Threatened) again according to IUCN categories. These taxa, which are very important in terms of preservation and maintenance of biological diversity, should be protected together with their living environments.

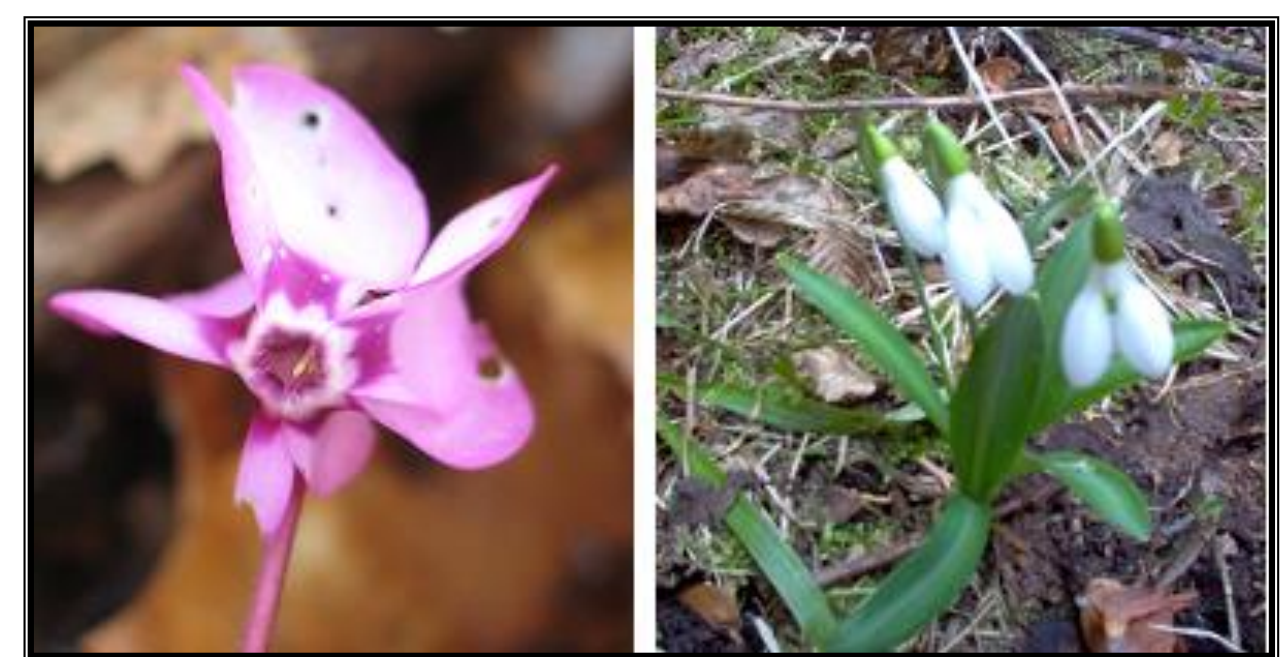

Figure 7. Cyclamen coum var. coum And Galanthus plicatus subsp. byzantinus

Gölderesi Waterfall, which consist of stable water surfaces and streams, are within the boundaries of the study area (Figure 8). Gölderesi is an important wetland system that hosts many bird species. It is observed that recreational use is not intense in the biotope which has great importance in terms of wildlife. In this context, the existing natural potential of the area should be revealed and necessary promotion should be made. At the stage of bringing the area in tourism, it is recommended to consider existing pressures and to evaluate the area according to sustainable ecotourism principles based on nature conservation- development. 


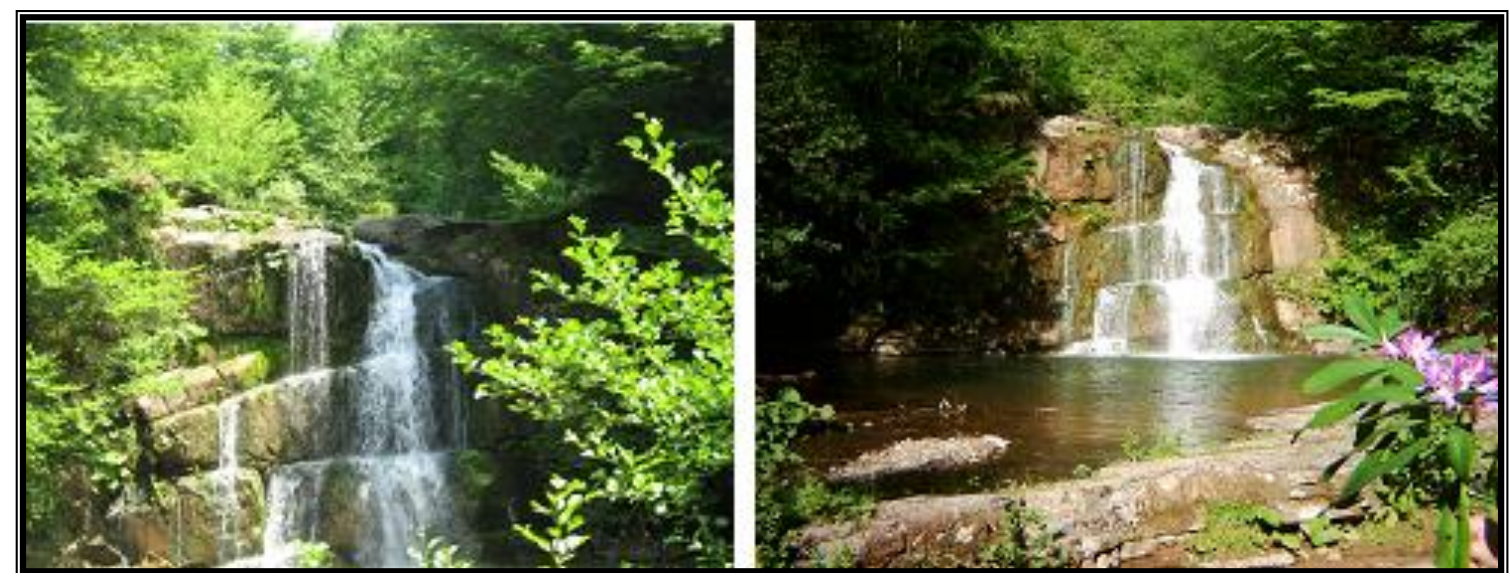

Figure 8. Gölderesi Waterfall

Flour mills are operated on Gölderesi, which is formed by streams and small lakes of various sizes, taking advantage of the current power of water (Figure 9). This supports ecological life and makes economic contribution to local people.

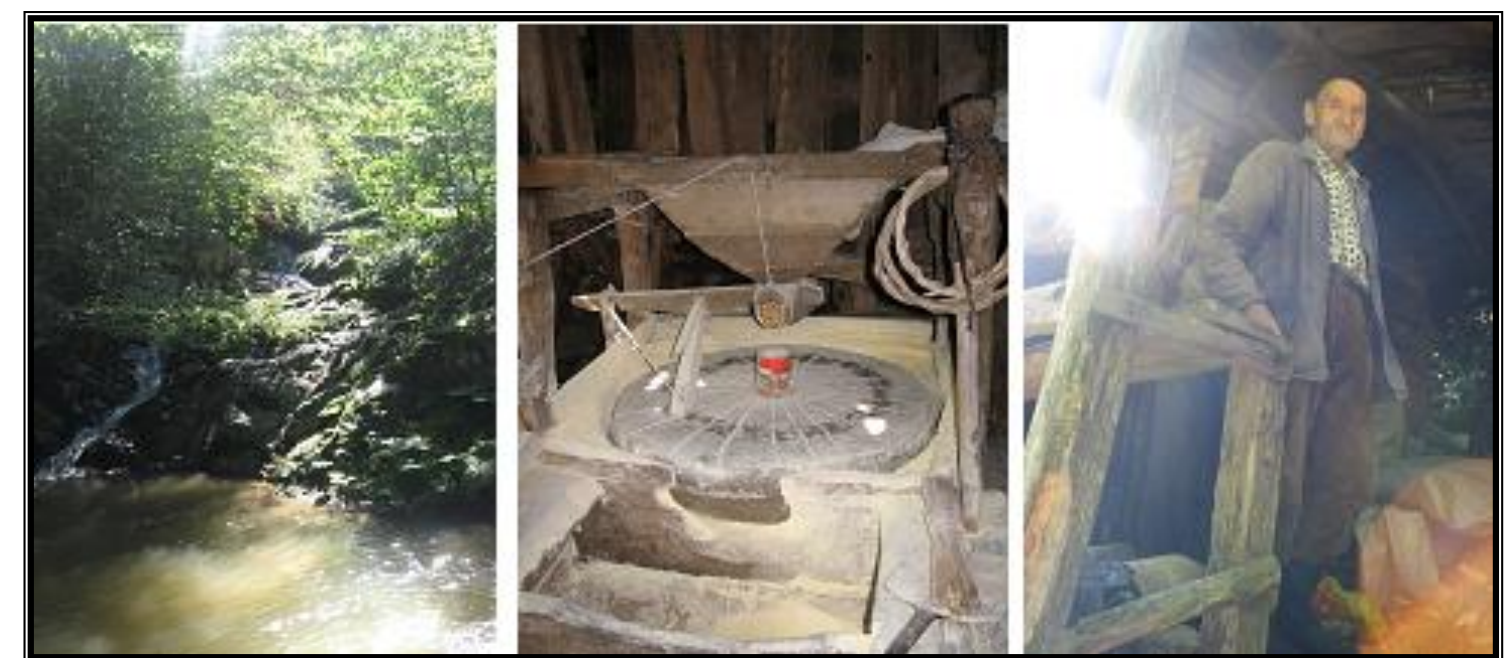

Figure 9. Flour Mill On The Gölderesi

A wetland inventory is a prerequisite for effective management and monitoring of wetlands, including the collection of relevant data describing the quality of resources and area units. Establishing region- specific inventories is an ideal method to help achieving nature conservation objectives. The results of the research are intended to constitute a basis for land use decisions and nature conservation studies.

\section{REFERENCES}

Akman, Y., Ketenoğlu, O., Kurt, L., Güney, K., Hamzaoğlu, E. \& Tuğ, N. (2007) Angiospermae (Kapalı tohumlular). Palme Yayınc1lı, ISBN: 9944- 341- 21- 5.

Altan, T. (2000) Doğal bitki örtüsü. Adana: Çukurova Üniversitesi Ziraat Fakültesi Genel Yayın No: 2353, Ders Kitapları Yayın No: A- 76.

Atalay, İ., Ekinci, D. \& Bayrak, M. (2019) Ecological problems based on anthropogenic process of some coastal wetlands in Turkey. 
https://www.academia.edu/19550651/Türkiye_Kiyılarındaki_Bazı_Sulak_Alanların_Antropo jenik_Süreçlere_Bağlı_Ekolojik_Sorunları (20/09/2019).

Başaran, S. (1998) Kirazlı̄k (Bartın) barajı florası. Zonguldak: Doktora tezi, Zonguldak Karaelmas Üniversitesi Fen Bilimleri Enstitüsü.

Baytop, T. (1997) Türkçe bitki adları sözlüğü. Ankara: Türk Dil Kurumu Yayınları: 578.

Braun- Blanquet, J. (1964) Pflanzensoziologie. New York.

Çakır, G. \& Çakır, A. (2019) The evaluation of ecotourism in wetland: İğneada example.

https://www.academia.edu/22878862/Sulak_Alanlar\%C4\%B1n_Ekoturizm_A\%C3\%A7\%C4 $\% \mathrm{~B} 1 \mathrm{~s} \% \mathrm{C} 4 \% \mathrm{~B} 1 \mathrm{ndan} \_\mathrm{De} \% \mathrm{C} 4 \% 9 \mathrm{Ferlendirilmesi}$ _The_Evaluation_Of_Ecotourism_In_ Wetland_I\%C4\%9Fneada_Example (10/05/2019).

Chokor B. A. (1992) Environmental pressure groups and habitat protection in the developing world: The case of Nigeria. The Environmentalist, 12 (3), 169- 180.

Çilsüleymanoğlu, S. (1996) Bartın halk kültürü. Ankara: Türk Tarih Kurumu Basımevi, (Cilt 1).

Davis, P. H. (1965- 1985) Flora of Turkey and The East Aegean Islands. Edinburgh: Edinburgh University Press (Volume 1- 2- 3- 4- 5- 6- 7- 8- 9).

Davis, P. H., Mill, R. R. \& Tan, K. (1988) Flora of Turkey and The East Aegean Islands. Volume 10, Edinburgh University Press, Edinburgh, 590 pp.

Durmuşkahya, C. (2006) Ege Bölgesinde doğal yayılış gösteren ă̆aç ve çalılar. Ankara: Çevre ve Orman Bakanlığı Doğa Koruma ve Milli Parklar Genel Müdürlüğü Biyolojik Çeşitlilik ve Doğal Kaynak Yönetimi Projesi, ISBN: 975- 8273- 86- 8.

Ekici, B. (2012) Mapping of the biotopes in the Kurucaşile (Bartın) coastline and its surrounding areas. Bartın: Doktora tezi, Bartın Üniversitesi Fen Bilimleri Enstitüsü.

Ekici, B. (2017) Some geophyte plants determined in Bartın/ Turkey. Biological Diversity and Conservation, 10 (1).

Ekim, T., Koyuncu, M., Vural, M., Duman, H., Aytaç, Z. \& Adigüzel, N. (2000) Türkiye bitkileri kırmızı kitabı (Eğrelti ve tohumlu bitkiler). Ankara: Türkiye Tabiatını Koruma Derneği Yayını.

Erik, S., Akaydın, G. \& Göktaş, A. (1998) Başkentin doğal bitkileri. Ankara: Ankara Valiliği Çevre Koruma Başkanlığ 1 .

Fitter, R., Fitter, A. \& Blamey, M. (1986) Pareys blumenbuch. London: Wild Pflanzen Deutschlands und Nordwesteuropas.

Gibbons, B. \& Brough, P. (1993) Blüten- pflanzen. Stuttgart: Franckh- Kosmos VerlagsGmbH \& Co., ISBN: 3- 440- 07504- 4.

Gren I. M., Folke, C. \& Turner, K. (1994) Primary and secondary values of wetland ecosystems. Environmental and Resource Economics, 4, 55- 74.

Güner, A., Özhatay, N., Ekim, T. \& Başer, K. H. C. (2000) Flora of Turkey and The East Aegean Islands. Edinburgh: Edinburgh University Press, (Volume 11).

Haner, B. \& Türk, Y. (2000) Batı Karadeniz havzasının maden kaynaklarl potansiyeli, işletebilirliği, beklentiler ve öneriler. Türkiye 12. Kömür Kongresi Bildiriler Kitabı, 2326 Mayıs 2000.

Hong, S. K., Song. I. J., Byun, B., Yoo, S. \& Nakagoshi, N. (2005) Applications of biotope mapping for spatial environmental planning and policy: Case studies in urban ecosystems in Korea. Landscape Ecology Engineering, 1, 101- 112.

Hora, B. (1981) The Oxford encyclopedia of trees of the world. Oxford: Oxford University Press.

Karadeniz, N., Tirıl, A. \& Baylan, E. (2009) Wetland management in Turkey: Problems, achievements and perspectives. African Journal of Agricultural Research, 4 (11), 11061119. 
Kaya, Z., Başaran, S. (2006) Bartın florasına katkılar. Gazi Üniversitesi Orman Fakültesi Dergisi, $6(1)$.

Kiymaz, S. (2010) Water resources management of Seyfe Lake wetlands and recomendation for resolve. e-Journal of New World Sciences Academy, 5 (2), 174- 185.

Kimmel, K., Kull, A. \& Salm, J. O. (2010) The status, conservation and sustainable use of Estonian wetlands. Wetlands Ecology Management, 18, 375- 395.

Korkanç, S. (2004) The role of wetlands in watershed system. Z. K. Ü. Bartın Orman Fakültesi Dergisi, 6 (6), 117- 126.

Kremer, B. P. (1998) Die bäume Mitteleuropas. Stuttgart: Kosmos, ISBN: 3- 440- 07604- 0.

Löfvenhaft, K., Björn, C. \& Ihse, M. (2002) Biotope patterns in urban areas: a conceptual model integrating biodiversity issues in spatial planning. Landscape and Urban Planning, 58, 223- 240.

Maraşlığlu, F. \& Salur, A. (2016) Biodiversity of lake Gölünyazı (Eymir). Uluslararası Bütün Yönleriyle Çorum Sempozyumu, 28 - 30 Nisan 2016.

Müller, R., Nowicki, C., Barthlott, W. \& Ibisch, P. L. (2003) Biodiversity and endemism mapping as a tool for regional conservation planning- case study of Pleurothallidinae (Orchidaceae) of the Andean rain forest in Bolivia. Biodiversity and Conservation, 12, 2005- 2024.

Namıkoğlu, N. G. (2007) Türkiye’nin ăgaçları ve çalıları. İstanbul: NTV Yayınları, ISBN: 978- 975- 6690- 80- 2.

Naveh, Z. (2007) Landscape ecology and sustainability. Landscape Ecology, (10), 1437- 1440.

Özbey, B. G., Kurt, L., Bölükbaşı, A., Özdeniz, E. \& Özcan, A. U. (2015) A research of Eregli reeds in respect to floristic diversity and plant dynamism (Eregli/ Konya). Kastamonu Üniversitesi Orman Fakültesi Dergisi, 15 (1), $49-57$.

Özhatay, N., Özhatay, E. \& Erdem, A. Ö. (2010) Şile’nin doğal bitkileri. İstanbul: Işık Üniversitesi Yayınları, ISBN: 978- 975- 6494- 02- 8, 1.

Ramsar Convention Bureau (1992) Ramsar convention, Slimbridge, England.

Ramsar Convention Secretariat (2018) Ramsar Convention on Wetlands, "Global wetland outlook: State of the world's wetlands and their services to people".

Sarı Nayim, Y., (2010) Amasra- Inkum (Bartın) arasında yer alan önemli biyotopların haritalanmast. İstanbul: Doktora Tezi, İstanbul Üniversitesi Fen Bilimleri Enstitüsü.

Sarı Nayim, Y., Ayaşligil, Y. (2015) Contributions to the flora between Amasra and İnkum (Bartın) located in Western Black Sea Region. Biological Diversity and Conservation, 8 (3).

Sarı Nayim, Y. (2017) Mapping of biotopes between Amasra and İnkum (Bartın), Western Black Sea Regon of Turkey. Journal of Environmental Biology, 38, 1033-1042.

Schönfelder, P. \& Schönfelder, I. (1990) Was blüht am mittelmeer. Stuttgart: Franckh- Kosmos Verlags- GmbH \& Co., ISBN: 3- 440- 05790- 9.

Schönfelder, P. \& Schönfelder, I. (1995) Der kosmos- heilpflanzenführer. Stuttgart: FranckhKosmos Verlags- GmbH \& Co., , ISBN: 3- 440- 06954- 0.

Seçmen, Ö., Gemici, Y., Görk, G., Bekat, L. \& Leblebici, E. (1995) Tohumlu bitkiler sistematiği. İzmir Ege Üniversitesi Fen Fakültesi Kitaplar Serisi No: 116.

Seçmen, Ö. \& Leblebici, E. (1997) Türkiye sulak alan bitkileri ve bitki örtüsü. İzmir: Ege Üniv. Fen Fak. Yayınları.

Shah, P. S. \& Ayiemba, E. H. O. (2019) Convention on biological diversity and rural- urban connections with reference to Kenya. International Journal of Research in Environmental Studies, 6, 14- 26.

Ssymank, A. \& Dankers, N. (1996) II. Red List of biotopes and biotope complexes of the Wadden Sea area. Helgoländer Meeresunters, 50, 9- 37. 
Symonds, W. D. \& Chelimsky, S. V. (1958) The tree identification book. New York: William Morrow and Company.

Symonds, W. D. \& Merwin, A. W. (1963) The shrub identification book. New York: William Morrow and Company.

Tutin, T. G., Burges, N. A., Chater, A. O., Edmondson, J. R., Heywood, V. H., Moore, D. M., Valentine, D. H., Walters, S. M. \& Webb, D. A. (1964) Flora Europeae. Cambridge: Cambridge University Press, (Volume 1).

Tutin, T. G., Burges, N. A., Heywood, V. H., Moore, D. M., Valentine, D. H., Walters, S. M. \& Webb, D. A. (1968- 1980) Flora Europeae. Cambridge: Cambridge University Press, (Volume 2- 3- 4- 5).

Uluocak, N. (1994) Yerörtücü bitkiler ders kitabı. İstanbul: İstanbul Üniversitesi Yayın No: 3874, Orman Fakültesi Yayın No: 428.

UN (2020) United Nation, World Day to Combat Desertification and Drought 17 June http://www.un.org/ en/events/desertificationday/background.shtml (Accessed 2020).

Wang, Y., Hong, W., Wu, C., He, D., Lin, S. \& Fan, H. (2008) Application of landscape ecology to the research on wetlands. Journal of Forestry Research, 19 (2), 164- 170.

Vurdu, H., Uslu, N., Güney, K., Ünal, S., Ayan, S., Sivacioğlu, A., Gürel, N., Küçük, Ö., Akyıldız, H., Ulushan, M.D., Öztürk, S., \& Türkyılmaz, E. (2004) Küre Dă̆g Milli Parkı'nın floristik zenginliği ve yaban hayatının belirlenmesi. Devlet Planlama Teşkilatı Projesi, Proje No: 2002K120250.

Yaltırık, F. (1988) Dendroloji ders kitabı II Angiospermae. İstanbul: İstanbul Üniversitesi Yayın No: 3509, Orman Fakültesi Yayın No: 390.

Yaltırık, F. \& Efe, A. (1996) Otsu bitkiler sistematiği. İstanbul: İstanbul Üniversitesi Yayın No: 3940, Orman Fakültesi Yayın No: 10.

Yatgın, H. (1996) Amasra yöresi floristik kompozisyonu. Zonguldak: Yüksek lisans tezi, Zonguldak Karaelmas Üniversitesi Fen Bilimleri Enstitüsü.

Yılmaz, O. (1993) Maki bitkileri. Ankara: Ankara Üniversitesi Ziraat Fakültesi Yayınları: 1326, Ders Kitab1: 325.

Yılmaz, H. (2001) Bartın kenti ve yakın çevresinin biyotoplarının haritalanması. Zonguldak: Doktora tezi, Zonguldak Karaelmas Üniversitesi Fen Bilimleri Enstitüsü.

Yılmaz, M. \& Çiçek, E. (2003) Forestry activities in and around riparian areas. Istanbul Üniversitesi Orman Fakültesi Dergisi, $52-53$ (2), 95- 109.

Yılmaz, H., (2004) Bartın kentinin çayır vejetasyonu üzerinde araştırmalar. Ekoloji Dergisi, 13, 26- 32 .

Zeydanlı, U., Erdoğan, M. K. \& Gemici, Y. (1999) Ankara: ODTÜ kampusu kır çiçekleri rehberi.

\section{APPENDIX}

Appendix 1. Vegetation Analiysis Of Wetland Biotopes

(Abbreviations: PTrc: Çakraz formation (Red sandstone- claystone), JKrz: Zonguldak formation (Limestone- dolomitic limestone), Krkz: Kazpınarı formation (Andesite- tuffagglomerate), Gr: Gray brown podzolic, P: Red yellow podzolic)

\begin{tabular}{|c|c|c|c|c|c|c|c|c|}
\hline & $\begin{array}{c}\text { Research area } \\
\text { number }\end{array}$ & 1 & 2 & 3 & 4 & 5 & 6 & $\begin{array}{c}\text { Availa } \\
\text { bility }\end{array}$ \\
\hline \multirow[t]{4}{*}{ NO } & Aspect & SE & SW & SW & $\mathrm{NE}$ & $\mathrm{N}$ & $\mathrm{N}$ & \\
\hline & Slope (\%) & 20 & 10 & 30 & 40 & 30 & 40 & \\
\hline & Geological structure & Çakraz & Çakraz & Çakraz & Çakraz & Zonguldak & Kazpınarı & \\
\hline & & f. & f. & f. & f. & f. & f. & \\
\hline
\end{tabular}




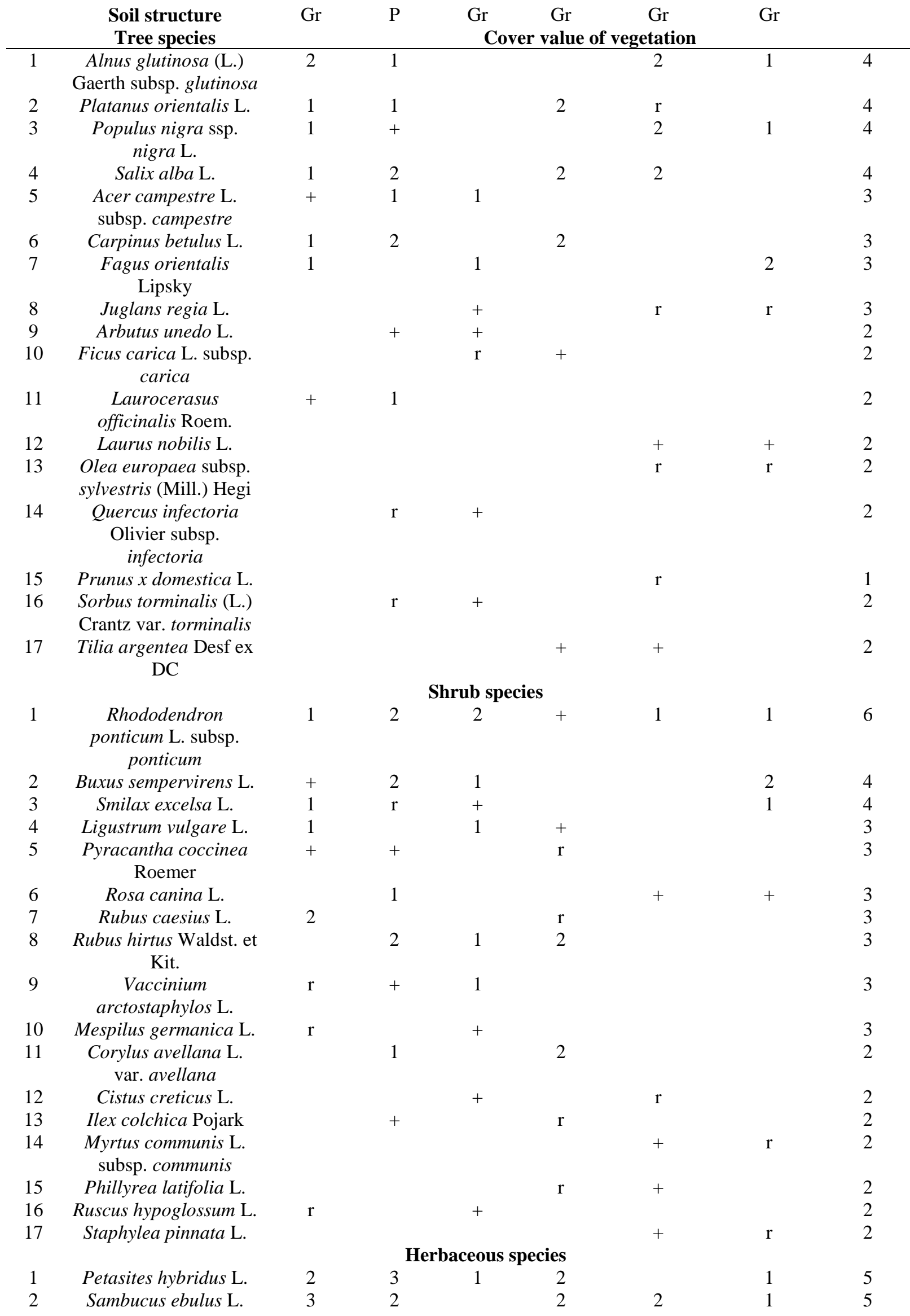




\begin{tabular}{|c|c|c|c|c|c|c|c|c|}
\hline 3 & $\begin{array}{c}\text { Anagallis arvensis L. } \\
\text { var. arvensis }\end{array}$ & + & + & & $\mathrm{r}$ & 1 & & 4 \\
\hline 4 & $\begin{array}{c}\text { Cynoglossum creticum } \\
\text { Mill. }\end{array}$ & 1 & 2 & 1 & & & + & 4 \\
\hline 5 & Galega officinalis L. & 1 & 2 & & 3 & & 2 & 4 \\
\hline 6 & $\begin{array}{c}\text { Hordeum murinum } \\
\text { subsp. leporinum } \\
\text { (Link) Arcang. var. } \\
\text { leporinum }\end{array}$ & 1 & + & & + & 2 & & 4 \\
\hline 7 & Lolium perenne L. & & 2 & & 2 & 2 & 2 & 4 \\
\hline 8 & $\begin{array}{c}\text { Lysimachia verticillaris } \\
\text { Sprengel }\end{array}$ & 2 & + & 3 & $\mathrm{r}$ & & & 4 \\
\hline 9 & Mentha aquatica L. & 2 & 2 & & & + & 3 & 4 \\
\hline 10 & Potentilla reptans $\mathrm{L}$. & 1 & 2 & 1 & & & 1 & 4 \\
\hline 11 & $\begin{array}{c}\text { Ranunculus } \\
\text { constantinopolitanus } \\
\text { (DC.) D’URV. }\end{array}$ & 1 & 3 & & 3 & 2 & 2 & 4 \\
\hline 12 & Rumex crispus L. & 2 & 1 & 2 & + & & & 4 \\
\hline 13 & $\begin{array}{c}\text { Veronica chamaedrys } \\
\text { L. }\end{array}$ & & + & 2 & + & & 2 & 4 \\
\hline 14 & $\begin{array}{c}\text { Chenopodium album } \mathrm{L} \text {. } \\
\text { subsp. album var. } \\
\text { album }\end{array}$ & + & & $\mathrm{r}$ & & & + & 3 \\
\hline 15 & $\begin{array}{c}\text { Convolvulus arvensis } \\
\text { L. }\end{array}$ & 1 & & & & 1 & + & 3 \\
\hline 16 & $\begin{array}{l}\text { Galium verum } \mathrm{L} . \\
\text { subsp. verum }\end{array}$ & & + & 1 & + & & & 3 \\
\hline 17 & Hedera helix L. & 1 & & + & & 2 & & 3 \\
\hline 18 & Leucojum aestivum $\mathrm{L}$. & & 1 & & 2 & & 1 & 3 \\
\hline 19 & $\begin{array}{l}\text { Lotus corniculatus L. } \\
\text { var. corniculatus }\end{array}$ & 1 & & 2 & 1 & & & 3 \\
\hline 20 & Orobanche ramosa $\mathrm{L}$. & + & & $\mathrm{r}$ & & $\mathrm{r}$ & & 3 \\
\hline 21 & $\begin{array}{l}\text { Primula vulgaris Huds. } \\
\text { subsp. vulgaris }\end{array}$ & + & & + & $\mathrm{r}$ & & & 3 \\
\hline 22 & $\begin{array}{l}\text { Pteridium aquilinum } \\
\text { (L.) Kuhn. }\end{array}$ & $\mathrm{r}$ & 1 & + & & & & 3 \\
\hline 23 & Typha latifolia L. & & 1 & & & 1 & 2 & 3 \\
\hline 24 & Anthemis cotula L. & 1 & & & & & 2 & 2 \\
\hline 25 & $\begin{array}{c}\text { Argyrolobium } \\
\text { biebersteinii P.W. Ball }\end{array}$ & & 1 & & 1 & & & 2 \\
\hline 26 & $\begin{array}{c}\text { Cerastium glomeratum } \\
\text { Thuill. }\end{array}$ & & $\mathrm{r}$ & & 4 & & & 2 \\
\hline 27 & $\begin{array}{c}\text { Cirsium hypoleucum } \\
\text { DC. }\end{array}$ & & & + & + & & & 2 \\
\hline 28 & $\begin{array}{c}\text { Crepis foetida subsp. } \\
\text { rhoeadifolia (M. Bieb.) } \\
\text { Celak. }\end{array}$ & + & & & & 1 & & 2 \\
\hline 29 & $\begin{array}{l}\text { Dorycnium graecum } \\
\text { (L.) Ser. }\end{array}$ & & 1 & & + & & & 2 \\
\hline 30 & $\begin{array}{l}\text { Erodium cicutarium } \\
\text { (L.) L'Her. ex Aiton } \\
\text { subsp. cicutarium }\end{array}$ & & + & & & $\mathrm{r}$ & & 2 \\
\hline 31 & $\begin{array}{l}\text { Euphorbia } \\
\text { amygdaloides L. var. } \\
\text { amygdaloides }\end{array}$ & + & & + & & & & 2 \\
\hline 32 & Galium palustre L. & & 1 & & + & & & 2 \\
\hline 33 & $\begin{array}{c}\text { Glaucium flavum } \\
\text { Crantz. }\end{array}$ & & & & & + & + & 2 \\
\hline
\end{tabular}


Lythrum salicaria $\mathrm{L} . \quad+$

Mentha x piperita $\mathrm{L}$.

Muscari neglectum Guss

Nasturtium officinale R. Br.

Poa trivialis L.

Prunella vulgaris L.

Sherardia arvensis L.

Trifolium hybridum L. var. hybridum

Trifolium lappaceum L. $\quad 1$ Veronica serpyllifolia

$$
\mathrm{L} \text {. }
$$

Arabis caucasica

Willd. subsp. caucasica Arabis turrita L. Barbarea vulgaris R.Br.

Bellis perennis $\mathrm{L}$. Cardamine hirsuta $\mathrm{L}$. Cardamine quinquefolia (M. Bieb.) Schmalh Griseb.

Cirsium vulgare (Savi) Ten.

Carduus nutans L. Coronilla varia L. subsp. varia

Crocus ancyrensis (Herbert) Maw.

Cyclamen coum Miller var. coum

Euphorbia helioscopia $\mathrm{L}$.

Fragaria vesca $\mathrm{L}$. Galanthus plicatus

Bieb. subsp. byzantinus (Baker) D.A. Webb Iris pseudacorus L. Polystichum setiferum (Forsk.) Moore ex Woynar Rapistrum rugosum (L.) All.

Rostraria cristata (L.) Tzvelev var. cristata Rumex conglomeratus Murray

Sedum stoloniferum S.G. Gmelin Sophora jaubertii Spach.

(L.) Schultz Bip. 
68 Torilis arvensis (Huds.) + Link. subsp. arvensis

69 Trifolium campestre Schreb.

$70 \quad$ Trifolium repens $\mathrm{L}$. subsp. repens

71 Tussilago farfara $\mathrm{L}$. Dominant species

Appendix 2. Coordinates Of Research Area Research area no Coordinates

\begin{tabular}{ccc} 
& X & Y \\
\hline 1 Başköy Stream & 4625650 & 475925 \\
2 Elvanlar Stream & 4626300 & 465150 \\
3 Gölderesi Waterfall & 4625550 & 469500 \\
4 İlyas Stream & 4628575 & 478075 \\
5 Kapısuyu Stream & 4632475 & 479550 \\
6 Tekkeönü Stream & 4630200 & 472700 \\
\hline
\end{tabular}

